\title{
Preparation of Novel Dideuterioallyl Mercaptan
}

\author{
Kyu Ok Jeon, Ji Sook Yu, and Chang Kiu Lee ${ }^{*}$ \\ Department of Chemistrv, Kangwon National University. Chincheon 200-701, Korea \\ Recened August 18, 2003
}

Kcy Words : Dideuterioallyl mercaptan, Acrylic acid. Propargyl alcohol, Reduction, Lithium aluminum hydride

Mass spectrometry is known to be the most accurate method for the quantitative analysis of flavor ingredients in food. For successful analysis with the method called "stable isotope dilution assay', the isotopically labeled compound of each component is necessary.' A difference in mass units of two or more gives the best results in the quantitative determination of each ingredient.

In order to analyze the allyl mercaptan present in the odor of bulgogi (a popular Korean dish) we needed to have allyl mercaptan-1, 1- $d_{2}$ or allyl mercaptan-2,3- $d_{2}$. Neithr compound has been reported in the literature. One of the logical schemes for the synthesis is to preparing corresponding allyl alcohol (2) and converting it to the corresponding mercaptan. Allyl alcohol- $d_{5}\left(\mathrm{CD}_{2}-\mathrm{CDCD}_{2} \mathrm{OH}\right)$ is commercially available, but the $-1,1-d_{2}$ or $-2,3-d_{2}$ alcohol is not. Allyl alcohol- $1,1-d_{2}$ has been reported to be prepared by reduction of acryloyl chloride with $\mathrm{LiAlD}_{4}{ }^{2}{ }^{2}$

There are numerous citations of the use of $\mathrm{LiAlH}_{4}$ for the reduction of $\alpha, \beta$-unsaturated carboxylic acids to alkenols. For example, a reference book states that lithium aluminum hydride reduces exclasively the carbonyl group. even in an unsaturated acid with $\alpha, \beta$-conjugated double bonds. ${ }^{3}$ The reference that was cited for the statement reported the reduction of acetylenedicarboxylic acid to 2-butene-1,4-diol ( $84 \%$ yield with $98 \%$ purity). fumaric acid to 2-butene-1,4diol ( $78 \%$ yield), acrylic acid (1) to allyl alcohol (2.68\% yield), and propiolic acid (5) to allyl alcohol (2, $85 \%$ yield). ${ }^{+}$

Allyl alcohol (2) was not reduced to $n$-propyl alcohol (3) under the conditions, but such reduction was accomplished in $26 \%$ yield by heating the mixture in dibutyl ether at 100 ${ }^{\circ} \mathrm{C}$ for $3 \mathrm{~h}^{5}$ It should be pointed out that 0.75 mole of $\mathrm{LiAlH}_{4}$ is required for reduction of $\mathrm{I}$ mole of $\mathrm{RCOOH}$ to $\mathrm{RCH}_{2} \mathrm{OH}$ and $\mathrm{H}_{2}$. But 0.283 mole of 1 and 0.35 mole of $\mathrm{LiAlH}_{4}$ in ether was reacted at room temperature for $16 \mathrm{~h}$ for the reduction of 1 to 2 . $^{4}$

Therefore, we attempted the reduction of acrylic acid (1) with $\mathrm{LiAlH}_{4}$ to establish the suitable reaction conditions which would be adapted for the reduction with LiAlD $_{4}$.

To our surprise the reaction was not as simple as described in the literature. ${ }^{3, t}$ When we slowly added acrylic acid (1) in ether to a mixture of $\mathrm{LiAlH}_{4}$ in ether at $0^{\circ} \mathrm{C}$, refluxed for 18 $h$, and followed the typical work-up procedure $\left(\mathrm{H}_{2} \mathrm{O}\right.$ and $\mathrm{NaOH}$ ) involving extraction with diethyl ether, the reaction mixture was quite complex. Its NMR spectrum clearly showed the presence of allyl alcohol (2) and n-propyl

"Corresponding author. e-mail: cklee4lo(ukangwon.ac.kr alcohol (3) in a ratio of ca. I: 8 (Table 1, Entry 1). There were also some unidentified compounds which could have formed from dimer ( $\left.\mathbf{1}^{\prime}\right)$ and trimer $\left(\mathbf{1}^{\prime \prime}\right)$ of $\mathbf{1}$.
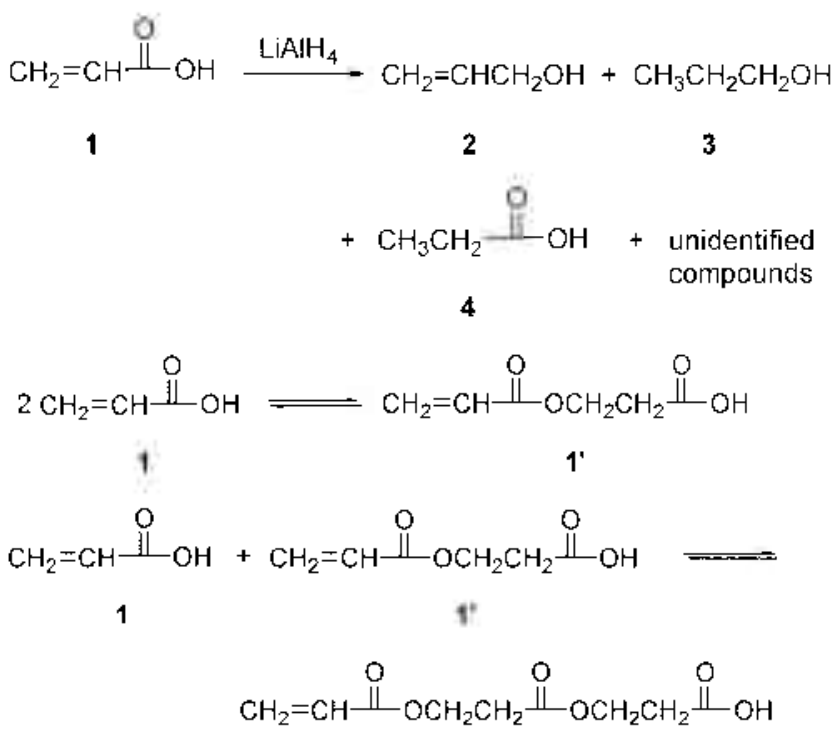

$1 "$

On the other hand, when the aqueous layer was acidified with aq. $\mathrm{HCl}$ and then extracted with diethyl ether, the starting acid (1) was recovered in about $5 \%$ yield along with propionic acid (4) in about $45 \%$ yield. The relative ratio of the products varied depending on the reaction conditions, but the recovery of the acids $\mathbf{1}$ and $\mathbf{4}$ was more than $50 \%$ in our attempts. Compound $\mathbf{3}$ was the major component in the ethereal extract as shown in lable I. It seems apparent that the reduction of 1 cannot be the method of choice because not only was the yield of $\mathbf{2}$ low but the separation of $\mathbf{2}$ from the mixture was difficult.

Propiolic acid (5) has also been known to give allyl alcohol (2). ${ }^{4}$ Reduction with $\mathrm{LiAlD}_{4}$ may give trideuterated allyl alcohol, which should be acceptable for preparation of a deuterated allyl mercarptan and eventually for the analysis of the odor component. However, our attempt to reduce 5 with $\mathrm{LiAlH}_{4}$ was also troublesome because not only 2 but 3 and propargyl alcohol (6) were also present in the reaction mixture (lable 1, Entries 3,4).

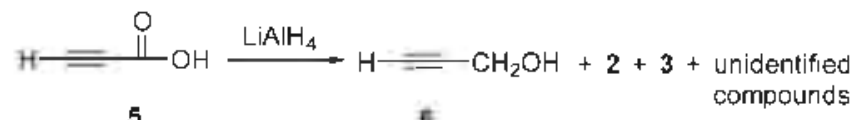


Table 1. Reduction of Aerylic Acid (1). Propiolic Acid (5). and Propargyl Alcohol (6) with $\mathrm{LiAlH}_{+}$in Dicthyl Ether

\begin{tabular}{|c|c|c|c|c|}
\hline lixp. & Subs." & $\mathrm{I} . \mathrm{Al} \mathrm{J}^{\mathrm{cr}}$ & Conditions & Products $(\%)^{\prime \prime}$ \\
\hline 1 & 1.32 & 44 & $\begin{array}{l}1 \text { to } \mathrm{L} A \mathrm{H} \text { at } O^{\prime \prime} \\
\text { reflux } 18 \mathrm{~h}\end{array}$ & $2(5) .3(42) .1(5)^{c} .4(45)$ \\
\hline 2 & 1.87 & 66 & $\begin{array}{l}1 \text { to } \mathrm{L} A \mathrm{H} \text { at } 0^{\circ} \\
\text { reflux } 8 \mathrm{~h}\end{array}$ & $2(8) .3(34) .1(15) .4(35)$ \\
\hline 3 & 5. 49 & 98 & $\begin{array}{l}5 \text { to L } \triangle \mathrm{H} \text { at } 0^{\circ} \\
0^{\circ} 2 \mathrm{~h} \text {. reflux } 8 \mathrm{~h}\end{array}$ & $2(44) .3(50) .6(6)$ \\
\hline 4 & 5. 49 & 98 & $\begin{array}{l}5 \text { to } \mathrm{LAH} \text { at } 0^{11} \\
\text { reflux } 2 \mathrm{~h}\end{array}$ & $2(40) .3(51)$ \\
\hline 5 & 6.52 & 39 & $\begin{array}{l}5 \text { to LAH at } 0^{\prime \prime} \\
\text { RT } 20 \mathrm{~h} \text {. retlux } 6 \mathrm{~h}\end{array}$ & $2(35) .6(60)$ \\
\hline 6 & 6.34 & 34 & $\begin{array}{l}5 \text { to } \mathrm{L} A \mathrm{H} \text { at } 0^{\prime \prime} \\
\text { reflux } 48 \mathrm{~h}\end{array}$ & $2(70) .6(5)$ \\
\hline 7 & 6.68 & 34 & $\begin{array}{l}5 \text { to } \mathrm{L} \Delta \mathrm{H} \text { at } 0^{\prime \prime} \\
\text { RT } 20 \mathrm{~h} \text {. retlux } 6 \mathrm{~h}\end{array}$ & $2(40) .6(50)$ \\
\hline
\end{tabular}

"Mmole. "Relative percentage. 'Recovery percent

The apparent failure to obtain $\mathbf{2}$ from $\mathbf{1}$ or $\mathbf{5}$ led us to investigate an alternative method, which is the reduction of 6 to 2 . There are a few reports ${ }^{6-8}$ related to similar reaction with alkynols of $H O C R^{1} R^{2} C=C-R^{3}$ to allyl alcohols HOCR ${ }^{\prime} \mathrm{R}^{2} \mathrm{CH}=\mathrm{CH}-\mathrm{R}^{3}$, but reduction of $6\left(\mathrm{R}^{1}=\mathrm{R}^{2}=\mathrm{H}\right)$ to 2 has not been reported. Since we have to have a dideuterated allyl alcohol, any procedure by which $\mathrm{D}_{2}$ component should add to a C-C triple bond should be useful, and naturally, we became interested in the mechanism of the conversion of 6 to 2 .

When a mixture of 6 and $\mathrm{LiAlH}_{1}(1: 1$ mole ratio) in diethyl ether was heated at reflux for $48 \mathrm{~h}$ and then quenched with aqueous $\mathrm{NaOH}, 2$ was the sole product in $70 \%$ yield (Table 1 . Entry 6 ). On the other hand, quenching with $\mathrm{NaOD}$ in $\mathrm{D}_{2} \mathrm{O}$ gave 3-deuterioallyl alcohols. 7 and 8 in a ratio of $10: 1$. Similar reaction of 6 with $\mathrm{LiAlD}_{4}$ and subsequent quenching with aqueous $\mathrm{NaOH}$ gave 2-deuterioallyl alcohol 9. Alternatively, quenching with $\mathrm{NaOD}$ in $\mathrm{D}_{2} \mathrm{O}$ gave a mixture of 2,3-dideuterioallyl alcohols $\mathbf{1 0}$ and $\mathbf{1 1}$ in a ratio of $9: 1$.

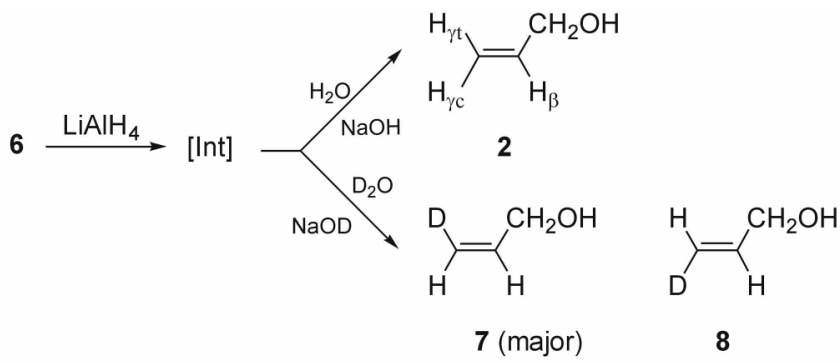<smiles>[2H]C=C([2H])CO</smiles>

The structures of the reduction products were readily confirmed by NMR spectroscopy as shown in Figure 1. The signal of $\mathrm{H}_{\beta}$ appears in the most downfield region ( $\delta 5.97$ ) as an overlapping $d d t$ with coupling constants of $17.2\left(J_{\beta . \gamma t}\right)$.

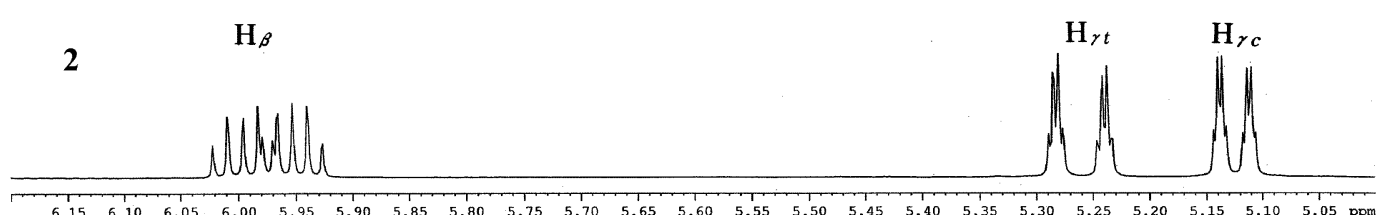

$7 / 8$

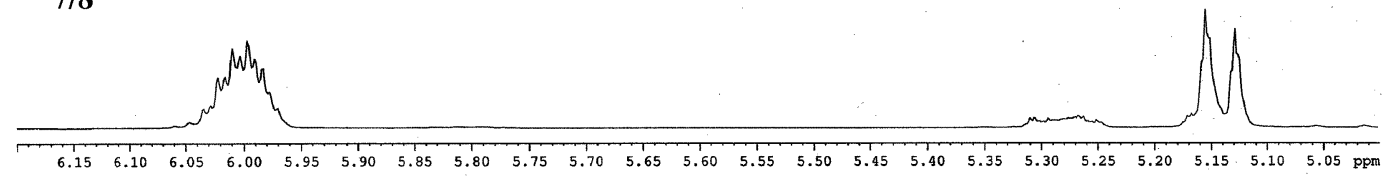

9

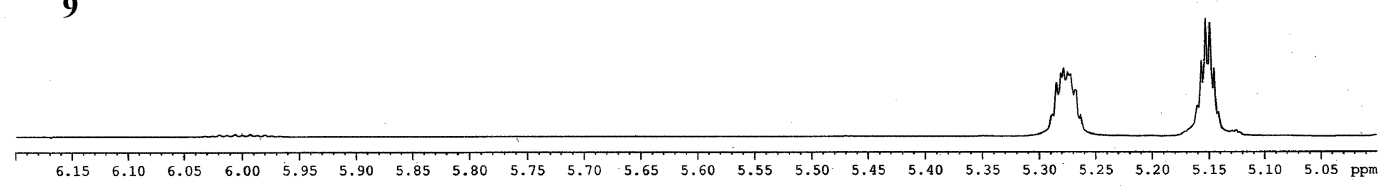

$10 / 11$

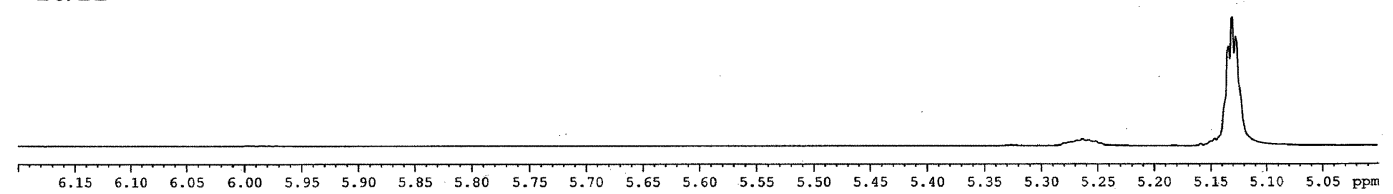

Figure 1. NMR spectra of the vinyl portion of allyl and deuterated allyl alcohols. 


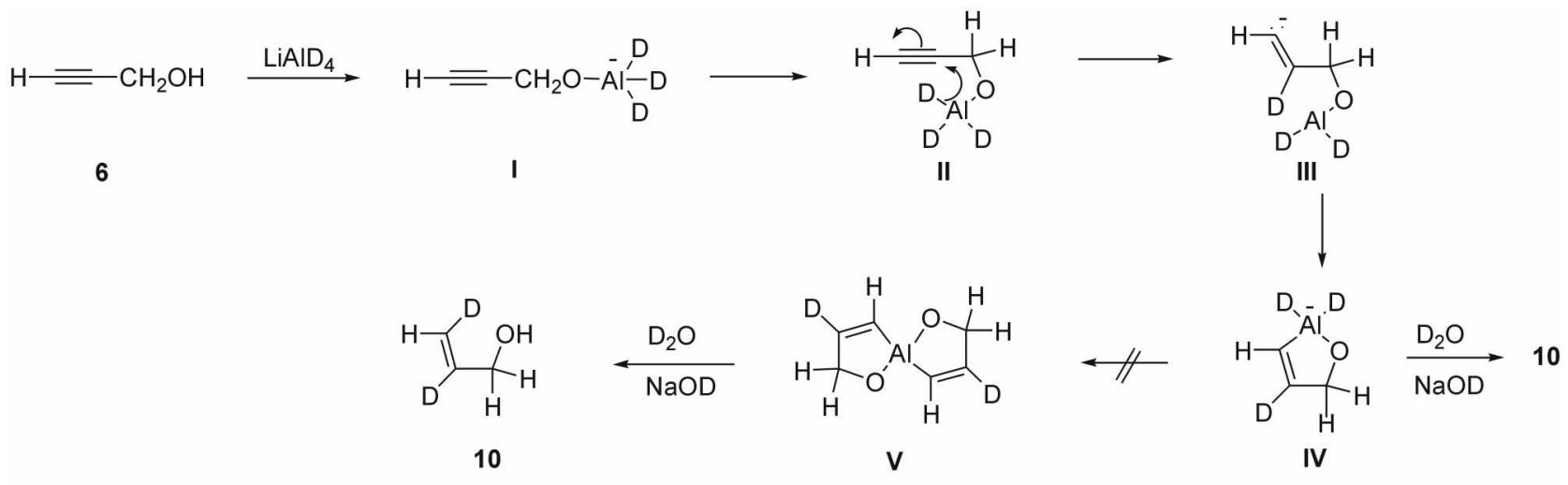

Scheme 1

$10.5\left(J_{\beta, c}\right)$ and $5.1\left(J_{\beta, \alpha}\right) \mathrm{Hz}$. The signals of $\mathrm{H}_{\gamma}$ and $\mathrm{H}_{\gamma}$ appear at $\delta 5.26$ and 5.13 , respectively. The disappearance of the signals in Figure 1 clearly shows the position of deuterium aton in the allyl alcolols 7-11

The positions of deuterium atoms in 7-11 strongly suggest a mechanism in which a hydride transfer from aluminum hydride to $\beta$-C of 6 like II as shown in Schente 1. Once an $s p^{2}$-hybridized carbanion forms, it may form a complex IV. Apparently. the complex IV is not reactive enough to form a bis-allyl complex such as $\mathbf{V}$. Instead it survives until being quenched by aqueous $\mathrm{NaOH}$. We tested the possibility by measuring the hydrogen gas evolved. During the stage of addition of 6 (68 mmol) to $\mathrm{LiAlH}_{4}(34 \mathrm{mmol})$ in diethyl ether, 1 equiv. (34 mmol) of hydrogen gas was evolved, but further generation of the gas was not observed during the reflux. Upon quenching about 2 equiv. ( $68 \mathrm{~mm}$ mol) of the gas was evolved. The quenched mixture was extracted with diethyl ether to give a mixture of 2 in $40 \%$ yield and 6 which together accounted for about $50 \%$ of the starting material. The result may be explained by two sets of stoichiometric equations as follows:

$$
\begin{aligned}
& 2 \mathrm{HC} \equiv \mathrm{C}-\mathrm{CH}_{2} \mathrm{OH}+\mathrm{LiAlH}_{4} \\
& \rightarrow\left[\left(\mathrm{CH}=\mathrm{CH}-\mathrm{CH}_{2} \mathrm{O}\right)_{2} \mathrm{Al}\right] \mathrm{Li}+2 \mathrm{H}_{2} \\
& {\left[(\mathrm{CH}=\mathrm{CH}-\mathrm{CH}-\mathrm{O})_{2} \mathrm{Al}\right] \mathrm{Li}+4 \mathrm{H}_{2} \mathrm{O}} \\
& \quad \rightarrow 2 \mathrm{H}_{2} \mathrm{C}=\mathrm{CH}-\mathrm{CH}_{2} \mathrm{OH}+\mathrm{Al}(\mathrm{OH})_{3}+\mathrm{LiOH} \\
& \mathrm{HC} \equiv \mathrm{C}-\mathrm{CH} \mathrm{H}_{2} \mathrm{OH}+\mathrm{LiAlH}_{4} \\
& \quad \rightarrow\left[\left(\mathrm{CH}=\mathrm{CH}-\mathrm{CH}_{2} \mathrm{O}\right) \mathrm{AlH}_{2}\right] \mathrm{Li}+\mathrm{H}_{2} \\
& {\left[(\mathrm{CH}=\mathrm{CH}-\mathrm{CH} O)_{2} \mathrm{AlH}_{2}\right] \mathrm{Li}+4 \mathrm{H}_{2} \mathrm{O}} \\
& \rightarrow \mathrm{H}_{2} \mathrm{C}=\mathrm{CH}-\mathrm{CH} \mathrm{H}_{2} \mathrm{OH}+\mathrm{Al}(\mathrm{OH})_{3}+\mathrm{LiOH}+2 \mathrm{H}_{2}
\end{aligned}
$$

If the reduction is to take place by Eqns. (1) and (2). quantitative amount of $\mathrm{H}_{2}$ gas should be formed during the stage of addition and reflux. On the other hand. Eqns. (1') and $\left(2^{\prime}\right)$ indicate that one equiv. of $\mathrm{H}_{2}$ should be formed at first and then two equiv. of the gas should be evolved during the quenching stage. Our observation is consistent with the latter.

It is known that alkynes which are not activated by an adjacent hydroxyl group react much more slowly with $\mathrm{LiAlH}_{4} .^{-}$Our observation that the $\mathrm{H}$ atom of the teminal alkyne does not exchange with $\mathrm{D}$ atom when $\mathrm{LiAlD}_{4}$ was used as reducing agent and a solution of $\mathrm{NaOD}$ in $\mathrm{D}_{2} \mathrm{O}$ was used for quenching clearly indicates that the hydride transfer from $\mathrm{LiAlH}_{4}$ to C.C triple bond is intramolecular as for II and not intermolecular. If it is intermolecular. the hydride should attack $\gamma-\mathrm{C}$ preferably on the grounds of stereoelectronic effect. Therefore, H-D exchange is likely to take place.

Finally, conversion of 10 to 2,3-dideuterioallyl mercaptan (12) was achieved by reacting with thiourea in aqueous $\mathrm{HCl}$ solution at $80^{\circ} \mathrm{C}$ for $24 \mathrm{~h}$ and subsequently quenching with aqueous $\mathrm{NaOH}$ solution. The final product was purified by distillation to give $46 \%$ yield.

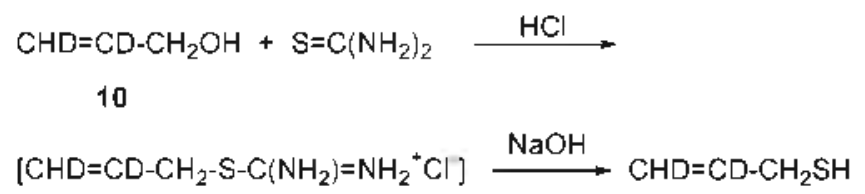

12

\section{Experimental Section}

General. Nuclear magnetic resonance (NMR) spectra were recorded on a Bruker DPX-400 FT NMR spectrometer in the Central Lab of Kangwon National University at 400 $\mathrm{MHz}$ for ${ }^{1} \mathrm{H}$ and $100 \mathrm{MHz}$ for ${ }^{13} \mathrm{C}$ and were referenced to tetramethylsilane. Infrared spectra were recorded on a JASCO FT/IR-460 Plus spectrophotometer. Mass spectra were obtained using Micromass Autospec M363.

Materials. Acrylic acid (1), propiolic acid (5), propargyl alcohol (6). $\mathrm{LiAlH}_{4} . \mathrm{LiAlD}_{4}$ and $\mathrm{NaOD}$ in $\mathrm{D}_{2} \mathrm{O}$ were used as received as the commercial products. Diethyl ether was distilled from over sodium metal prior to use.

Reduction of Acrylic Acid (1): A Representative Procedure. A mixture of $\mathrm{LiAlH}_{4}(2.5 \mathrm{~g} .66 \mathrm{mmol})$ and diethyl ether $(120 \mathrm{~mL})$ was cooled to $0^{\circ} \mathrm{C}$. Acrylic acid $(96.0 \mathrm{~mL} .87 \mathrm{mmol})$ was added in drops while the generated $\mathrm{H}_{2}$ gas was collected in a graduated cylinder. The mixture was heated at reflux for $8 \mathrm{~h}$ and then cooled in an ice-water bath. Water $(2.5 \mathrm{~mL}) .15 \%-\mathrm{NaOH}(2.5 \mathrm{~mL})$, and then water $(7.5 \mathrm{~mL})$ were added in sequence. and the resulting mixture 
was extracted with ether $(3 \times 50 \mathrm{~mL})$. The pooled ethereal extract was dried over $\mathrm{MgSO}_{4}$. Then the ether was removed by fractional distillation using a Vigreux columun. The residual liquid was analyzed by NMR spectroscopy showing that it was a mixture of allyl alcohol (2) and l-propanol (3) in a ratio of $1: 8$, and unidentified conpounds. The aqueous layer was acidified with $2 \mathrm{M}-\mathrm{HCl}$ to $\mathrm{pH} 4$ and then extracted with ether to give the starting acid and propionic acid (4) in a ratio of $1: 9$.

Reduction of Propiolic Acid (5): The procedure is essentially similar to the reduction of 1 . The acid $5(3 \mathrm{~mL}, 49$ mmol) was added to a mixture of $\mathrm{LiAlH}_{4}(3.72 \mathrm{~g} .98 \mathrm{mmol})$ in ether $(130 \mathrm{~mL})$ at $0{ }^{\circ} \mathrm{C}$, and the resulting mixture was heated at reflux for $12 \mathrm{~h}$. Quenching with aqueous $\mathrm{NaOH}$ and extraction with ether gave a mixture of $6(6 \%) .2(40 \%)$. and $3(51 \%)$

Reduction of Propargyl Alcohol (6): A Representative Procedure. The alcohol $6(2 \mathrm{~mL} .34 \mathrm{mmol})$ was added to $\mathrm{LiAlH}_{4}(2.20 \mathrm{~g} .52 \mathrm{~mm}$ ol $)$ in ether $(100 \mathrm{~mL})$ at $0{ }^{\circ} \mathrm{C}$ and the resulting mixture was heated at reflux for $12 \mathrm{~h}$. Quenching with aqueous $\mathrm{NaOH}$ and subsequent extraction with ether gave a mixture of $2(75 \%)$ and 6 ( $20 \%$ recovery).

Preparation of $\boldsymbol{\beta}$-deuterioallyl alcohol (9). The alcohol 9 was prepared by following the procedure for the reduction of 6 above except the quenching with $\mathrm{NaOD}-\mathrm{D}_{2} \mathrm{O}$ in $50 \%$ yield.

Preparation of trans- $\beta, \gamma$ dideuterioallyl alcohol (10). The alcohol 10 was prepared by following the procedure for the reduction of 6 above using $\mathrm{LiAlD}_{4}$ in same scale and subsequent quenching with $\mathrm{NaOD}-\mathrm{D}_{2} \mathrm{O}$. The isolated product $(44 \%)$ was a mixture of 10 and 11 in a ratio of $9: 1$ by NMR. Repeated column chromatography with silica gel with hexane-EtOAc $(9: 1)$ gave essentially pure form of $\mathbf{1 0}$.

Preparation of $\boldsymbol{\beta , \gamma}$ dideuterioallyl mercaptan (12). Conc. $\mathrm{HCl}(2.2 \mathrm{~mL})$ was added to a solution of thiourea $(1.81 \mathrm{gg} .24 \mathrm{mmol})$ in water $(2 \mathrm{~mL}) . \beta, \gamma$ Dideuterioallyl alcohol (10. 1.4 g. 23 mmol) was slowly added to the solution. The resulting solution was heated at $80^{\circ} \mathrm{C}$ for $24 \mathrm{~h}$ After cooling to room temperature, a solution of $\mathrm{NaOH}$ $(1.50 \mathrm{~g})$ in water $(2 \mathrm{~mL})$ was added slowly. The solution was fractionally distilled to give 12 as a colorless liquid in $46 \%$ yield. IR (neat): 3079 (w, $=\mathrm{C} \cdot \mathrm{H}$ ). 2923 (ms. $\mathrm{CH}_{2}$ ). 2558 (w. S-H). 1617 (ms. C $=$ C), 1410 (ms. CH $), 1220$ (m. C-S), 919 (s. $\mathrm{C}=\mathrm{C} \cdot \mathrm{H})$ ) ${ }^{1} \mathrm{H}-\mathrm{NMR}\left(\mathrm{CDCl}_{3}\right) \delta 1.43$ (t. I H. S-H. $J=7.7$ Hz). 3.17 (d. $2 \mathrm{H}, \mathrm{CH}_{3}, J=7.6 \mathrm{~Hz}$ ), $5.0 \mathrm{l}$ (brs. $\mathrm{lH} . \mathrm{C}=\mathrm{C} \cdot \mathrm{H}$ ); ${ }^{13} \mathrm{C} \cdot \mathrm{NMR}\left(\mathrm{CDCl}_{3}\right) \mathrm{ppm} 27.45\left(\mathrm{CH}_{2}\right) .115 .16$ (t. CHD, $J=$ $23.4 \mathrm{~Hz}$ ). 136.90 (t. CD. $J=24.0 \mathrm{~Hz}$ ): Mass. $\mathrm{m} / \mathrm{z}(\%) 152$ $\left(100\right.$, dimeric $\left.\mathrm{M}^{+}\right) .108\left(84\right.$. dimeric $\left.\mathrm{M}^{+}-\mathrm{CH}_{3} \mathrm{~S}\right) .75(74$. $\mathrm{CHD}=\mathrm{CD}-\mathrm{CH}_{2} \mathrm{~S}^{-}$).

Acknowledgements. We thank Dr. Gary Kwong of $3 \mathrm{M}$ Co. for proof-reading the manuscript. This work was supported by the Technology Development Program for Agriculture and Forestry, Ministry of Agriculture and Forestry. Korea (Grant No. 201013032HDl10).

\section{References}

1. Werkhoff, P: Brennecke. S.; Bretschneider. W: Bertram, H.-P. In Flavor: Fragrance, and Odor Anatysis: Marsili. R.. Ed.: Marcel Dekker: New York. 2002: pp 179-194.

2. Casey. C. P.: Vosejpka. P. C.: Underiner. T. L.: Slough. G. A.: Gavney. Jr.. J. A. J. Am. Chent Soc. 1993, 115.6680.

3. Hudlicky. M. Redactions in Organic Chemistry: Halsted Press: 1984: 138

4. Benedict. G.: Russell. R. R. J.Am. Chem. Soc. 1961. 73.5444.

5. Hochstein. F. A.: Brown. W. G. J. Ant Chem. Soc. 1948. 70. 3484 .

6. Bates. E. B.: Jones, E. R. H.: Whiting, M. C. J. Chem. Soc. 1954 1854.

7. Magoon. E. F; Slaugh, L. H. Tetrahedron 1967, $23,4509$.

8. Corey. E. I.: Katzenellenlogen. T. A.: Posner. G. H.. .Am. Chem. Soc. 1967.79 .4245 .

9. Hochins. R. O.: Hutchins. M. G. K. Reduction of Triple-bonded Groups in The Chentistry of Triple-bonded Functional Groups. Part 1. Supplement C. Patai, S.. Rappoport. Z., Eds.; John Wiley \& Sons: 1983; p 578 . 